\title{
MANAGING ASSETS OF AGRICULTURAL PROPERTY OF THE NATIONAL TREASURY IN THE CONTEXT OF STATE AID GRANTED BY THE AGRICULTURAL PROPERTY AGENCY ${ }^{1}$
}

\author{
Wiesława Lizińska, Assis. prof., PhD \\ Department of Economic and Regional Policy \\ University of Warmia and Mazury in Olsztyn \\ e-mail:wieslawa.lizinska@uwm.edu.pl
}

Renata Marks-Bielska, Assoc. prof., PhD

Department of Economic and Regional Policy

University of Warmia and Mazury in Olsztyn

e-mail:renatam@uwm.edu.pl

Karolina Babuchowska, PhD

Department of Economic and Regional Policy

University of Warmia and Mazury in Olsztyn

e-mail:karonat@poczta.onet.pl

Izabela Serocka, M.Sc.

Department of Economic and Regional Policy

University of Warmia and Mazury in Olsztyn

e-mail: izabela.serocka@uwm.edu.pl

\begin{abstract}
This study covers the issue of activities of the Agricultural Property Agency in terms of state aid in the form of non-repayable financial aid, with the following specific objectives: determining the scale and diversity of state aid granted by the APA (including the local branch in Olsztyn), evaluating the current technical condition of some of the assets and their condition upon being handed over by the APA, determining their importance, main problems associated with resources which are taken over, identifying and assessing the importance of actions which encourage communes to take over property still held by the APA, assessing the scale and procedure of aid granted in the opinion of representatives of APA units. The article makes use of information obtained from the local branch of the APA in Olsztyn in the years 2003-2014. A direct survey among the entities was taken. The survey questionnaire was sent in 2014 to all communes (gminas) of the Province (Voivodeship) of Warmia and Mazury (116 units). Completed questionnaires were returned by 73 representatives of the communes. A total of PLN 327.1 million was allotted in the Agency's financial plans for the program of non-repayable financial aid during the period from 2009 to 2014 . Approximately $81.6 \%$ of PLN 164.4 million granted by the local branch of the APA in Olsztyn, was granted to units of the public finance sector. As was shown in the survey conducted among representatives of local governments, the interest of communes in taking over assets still held by ${ }^{2}$ the local branch of the APA in Olsztyn could be increased by limiting the number of tenants who do not pay the rent regularly and by increasing the amount of non-repayable financial aid. It is possible to carry out the latter action, but the former could prove to be extremely difficult.
\end{abstract}

1 Publikacja dofinansowana przez Agencję Nieruchomości Rolnych 
Key words: state aid, Agricultural Property Agency, assets of agricultural property.

JEL Classification: E63, Q15, Q18, R14.

Citation: Lizińska W., Marks-Bielska R., Babuchowska K., Serocka I., 2015, Managing Assets of Agricultural Property of the National Treasury in the Context of State Aid Granted by the Agricultural Property Agency, Real Estate Management and Valuation, Vol. 23, No. 3, pp. 99-109.

DOI: $10.1515 /$ remav-2015-0029

\section{State aid as an instrument of state interventionism}

The influence of public authorities on the economy in the modern world is multidimensional, and the use of interventionist instruments in economic policy is common and substantial (SOSNOWSKI 2011). The main aim of the state's economic policy is to increase the effectiveness of the market system. In order to alleviate the imperfectness of the market, the state performs corrective actions. Instruments of the state's policy include state aid, which serves the purpose of pursuing economic, social and sometimes political objectives (RUTKIEWICZ 2014).

The state has intervened in the economy since the dawn of civilization. As early as in the antiquity, slave labor and land ownership were regulated by the state. The issue of state interventionism is still an object of lively discussions. Opponents of interventionism follow the train of thought of A. Smith, D. Ricardo, M. Friedman, who were in favor of the limited presence of the state in the economy. Others are closer to the views of J.G. Fichte, J.M. Keynes, or K. Marx, arguing for the need for the state's intervention in the economy (STANKIEWICZ 2007).

Interventionism as an economic trend emerged at the turn of the 19th and the 20th century as a result of the accumulation of negative social and economic tendencies. Its aim was to achieve a higher level of social justice. It is also argued that a policy of more active state intervention in the economy is justified by so-called market flaws (SOSNOWSKI 2011).

Interventionism, which brings more benefits than loss, should be characterized by comprehensiveness, links with the real economic processes and relative stability. One of the methods of supporting the economy is to provide benefits to specific entities, also known as state aid.

Stiglitz (2004), who saw the flaws of the market mechanism and was in favor of state intervention in the economy, also pointed to the lower effectiveness of state-run programs than those carried out by the private sector. Relevant legal regulations are applied in order to increase the relatively lower effectiveness of public programs. A requirement for the beneficiary of aid to contribute his own input, defined as the percent of the whole budget of a project, is imposed in order to increase financial discipline. Restrictions in the amount of aid have also been imposed in the form of amount- and timerelated limits in the aid provided to an entity (NARLOCH 2013).

State aid is the most common form of state intervention in both the economic and social sphere of a market economy. It provides specific benefits to entities, using instruments and institutions of the public sector for this purpose (PIETRZAK et al. 2006). State aid is a multi-aspect issue; it is one of the most complex areas in the EU.

\section{The essence of state aid}

State aid is an interdisciplinary category, which is defined depending on the approach of the area it applies to, taking into account, for example, economic sciences, legal aspects, social causes and effects (MÜLLER-IBOLD 2014). Basic differences in opinions on the justifiability of granting such aid result from the specific approach of a given researcher and differences of opinions regarding the role of the state in the economy, its functions and scope of competences (NARLOCH 2013).

There is no strict, classical definition of state aid in the legal acts of the European Union. There are only criteria of aid which do not comply with the market principles as laid down in the Treaty on the Functioning of the European Union (TFEU) (BLAUBERGER 2009). Issues associated with state aid are regulated both by provisions of the primary and secondary law, but it is the TFEU that is the basic source of EU policy towards state aid. The main regulations are laid down in Art. 107, 108, 109 of the TFEU (former Art. 92, 93, 94 TFEU). The Treaty also contains provisions which regulate state aid in 
agriculture - Art. 42 TFEU, transport - Art. 93, 96, 98 TFEU. Moreover, separate provisions regulate state aid for public enterprises - Art. 106 sect. 2 TFEU (MARQUARDT 2007).

According to the guidelines of the European Commission, the system of monitoring state aid in Poland is based on identifying four main groups of forms of such aid: group A (tax subsidies and grants), group B (capital and investment subsidies), group C (so-called soft crediting) and group $\mathrm{D}$ (credit guarantees). As some forms of state aid cannot be categorised into any of these groups, another group was created: E - other. Each group may contain active aid in the form of money spent by the budget or other public funds (marked by digit 1 ) and passive aid in the form of reduced budget or para-budget income (marked by digit 2) (SOSNOWSKI 2011).

There is a general assumption of a total ban on aid from public funds in the EU regulations. Aid that can be regarded as forbidden must meet four conditions simultaneously, called the conditions of admissibility of state aid, i.e: aid from the state, selectivity, anti-competitiveness and a negative impact on trade between member states (KISIEL et al. 2014, PODSIADŁO 2013). An assessment of whether state aid has been granted or not is made not of entities of groups thereof, but of transactions concluded between entities and, specifically, of the nature of such transactions and their effects ${ }^{3}$.

Since it happens very often that the benefits from state aid exceed the harm that it may cause, although it meets the conditions of the treaty ban, it is nonetheless called admissible aid.

It is assumed when such aid is granted that it is the intention of the state to restore the status quo that existed before the interfering factor, such as a natural disaster, occurred, rather than to improve the condition of certain entities at the expense of others. Competition protection is regarded as less important, and the aid as complying with the market principles; therefore, such state aid can be granted automatically (Pomoc ... 2009).

According to the principles of granting aid, a functional criterion is applied here. What matters is the economic nature of the activities, i.e. whether the beneficiary supplies goods to the market or provides a service rather than the forms of activities or whether it is being conducted for profit or not. In this approach, "an entrepreneur" also denotes organizations of the social (associations, foundations) and public sector (state-run and local government units, if they take part in the trade of goods or services which can be the object of trade between member states) (KUBERA 2013).

\section{Activity of the Agricultural Property Agency in the area of state aid}

Considerations published in literature on the subject of state interventionism have been inconsistent in their assessment of the effectiveness of market mechanisms in agriculture. Land management, which is an element of state policy, is of special importance, as this is a consequence of the specific features of such resources (the aggregate short-term supply of land is inflexible and insensitive to price fluctuations. If used rationally, land does not wear out during the production process. It is also a production factor that is spatially immobile. Non-expandable land resources are the object of competition between: agriculture, urbanization, forestry, recreation and environmental protection (MARKS-BIELSKA 2012, 2013), as well as investors (SZREDER, WALENTYNOWICZ 2014). Agricultural land is a valuable and non-renewable component of national assets and, for this reason, intervention in these resources is necessary, as is the case in other highly-developed countries (LINNER, MESSINGA 2012, MARKS-BIELSKA 2012).

A study conducted by Marks et al. (2013) showed that, apart from the typical ordinary assignments associated with ownership transformations carried out by the Agricultural Property Agency, the following were usually regarded as necessary, prospective actions by members of the APA personnel - branch managers: creating a favourable investment climate for domestic and foreign investors (68.8\% of the respondents), increasing the role in the multi-functional development of rural areas $(43.8 \%)$, returning to the social assignments associated with material aid provided to the areas of former state-run agricultural farms (37.5\%); every fourth respondent suggested an increase in the role of the Agency in the sustainable development of rural areas.

The aim of the aid program for people living in areas of former state-run agricultural farms is to provide non-repayable financial aid to communes (gminas) and cooperatives which will take over, free of charge, inhabited apartments and buildings and technical infrastructure facilities from the Agricultural Property Agency together with the liabilities with which they are burdened, without the

\footnotetext{
${ }^{3}$ www.bsskancelaria.pl. 19.12.2012
} 
Agency having to bring such facilities up to proper technical condition (Program...2009).

Non-repayable financial aid is granted by the Agricultural Property Agency under the Regulation of the Minister of Agriculture and Rural Development of 16 March 2009 on detailed rules of financial management at the Agricultural Property Agency and the financial management at the Agricultural Property Assets of the National Treasury (Journal of Laws No. 52, item. 427). Provisions regarding proceedings in cases regarding state aid apply to non-repayable financial aid, referred to in Section 3.2 of the Regulation.

The procedure for granting the aid is described in the Ordinance of the President of the Agency No. 14/2004 of 5 October 2004 on the conditions and rules of granting non-repayable financial aid by the Agency of Agricultural Property, amended by the Ordinance of the President of the Agency No. 35/08 of 29 October 2008.

Decisions on granting non-repayable financial aid are taken by the head of a local branch upon the written application of a beneficiary or on his/her initiative, after consulting representatives of former employees of state-owned agricultural farms. Non-repayable financial aid in the amount exceeding PLN 300,000 for purposes specified in \$ 2.1.1.of the ordinance, i.e. to aid beneficiaries mentioned in this Program, must be approved by the President of the Agency. The head of a local branch grants non-repayable financial aid within the limit at his/her disposal in the financial plan of the Resource.

Implementation of the program includes supporting activities, which mainly focus on: reviews by local branches of concluded agreements on the free-of-charge transfer of property ${ }^{4}$, property of the Agricultural Property Assets of the National Treasury which - according to the local branch - can be offered to communes or cooperatives free of charge ${ }^{5}$, propagation of rules of receipt and granting of non-repayable financial aid 6 , possible legislation initiatives undertaken by the Minister of Agriculture and Rural Development aimed at altering the provision of Art. 44 of the Act on Managing Agricultural Property of the National Treasury ${ }^{7}$.

\section{Goal and methodology of the study}

As the study covers the issue of activities of the Agricultural Property Agency in terms of state aid in the form of non-repayable financial aid, the following specific objectives were formulated:

- determination of the scale and diversity of state aid granted by the APA, including the local branch in Olsztyn,

- evaluation of the current technical condition of parts of the assets and their condition upon being handed over by the APA,

- determination of their importance, the main problems associated with the resources which are taken over, identification and assessment of the importance of actions which encourage communes to take over property still held by the APA,

- assessment of the scale and procedure of aid granted in the opinion of representatives of units.

The article makes use of information obtained from the local branch of the APA in Olsztyn on the execution of property transfer agreements in the years 2003-2014 (broken down into public finance sector units and other units) and non-repayable financial aid granted to those units.

Carrying out specific objectives also required a direct survey among the entities to whom property from the APA was handed over and those which have benefited from state aid granted by the local branch of the APA in Olsztyn in the Voivodeship (Province) of Warmia and Mazury. The execution of

\footnotetext{
4 under Art. 43.2, Art. 44 and Art. 48 of the Act, and a listing of assets handed over free of charge, whose repair can be subsidized by the Agency under valid regulations, and their new owners have not applied for such subsidies yet, or they have and the subsidy has not yet been granted.

5 under Art. 43.2, Art. 44 and Art. 48 of the Act and preparing a schedule of actions necessary for their handing over free of charge.

${ }^{6}$ propagation among communes and cooperatives which have taken over or could take over assets free of charge, while at the same time they could receive non-repayable financial aid, which should contribute to increasing the interest in taking over, free of charge, the property on offer under the conditions proposed by the Agency. Local branches conduct training sessions whose aim is to explain the rules and conditions under which it is granted to entities which can apply for non-repayable financial aid.

7 in order to make it possible to hand over, free of charge, technical infrastructure which is not part of the property, for example, boiler systems and water and heat supply and sewerage systems, which will enable the Agency to grant non-repayable financial aid if such infrastructure is handed over without being brought to a satisfactory technical condition.
} 
property transfer agreements has been provided since the year 2003, while the information provided by the ANR OT Olsztyn shows that, for all communes, such property has been transferred. Therefore, a survey questionnaire was sent in 2014 to all communes of the Province of Warmia and Mazury (116 units). Completed questionnaires were returned by 73 representatives of local governments (return rate of $63 \%$ ).

When the technical condition of the resources and the issues associated with taking over the property were determined, an index ${ }^{8}$ was used, calculated from the following formula:

$$
W=\frac{\sum_{i=1}^{k} n_{i} w_{i}}{k \cdot N},
$$

$W$ - importance index, $i$ - evaluation index, $n_{i}$ - the number of respondents who indicated the factor at the $i$-th position, $k$ - maximum score on the scale from 1 to $\mathrm{k}$ (indicating a sequence of factors was equivalent to assigning them marks in the reverse order), $N$ - the number of respondents who answered the question, $w_{i}$ - mark which corresponds to the place of factor $i$.

\section{Implementation of the program of non-repayable financial aid}

A total of PLN 327.1 million was allotted in the Agency's financial plans to the program of nonrepayable financial aid to communes, housing cooperatives and government and communal entities which took over devices, facilities and networks under Art. 24.6 of the Act during the period from 2009 to 2014 (Fig. 1). The aid was mainly granted to public finance units, as such units previously received the property under Art. 43.2, Art. 44 and Art 48 of the Act.

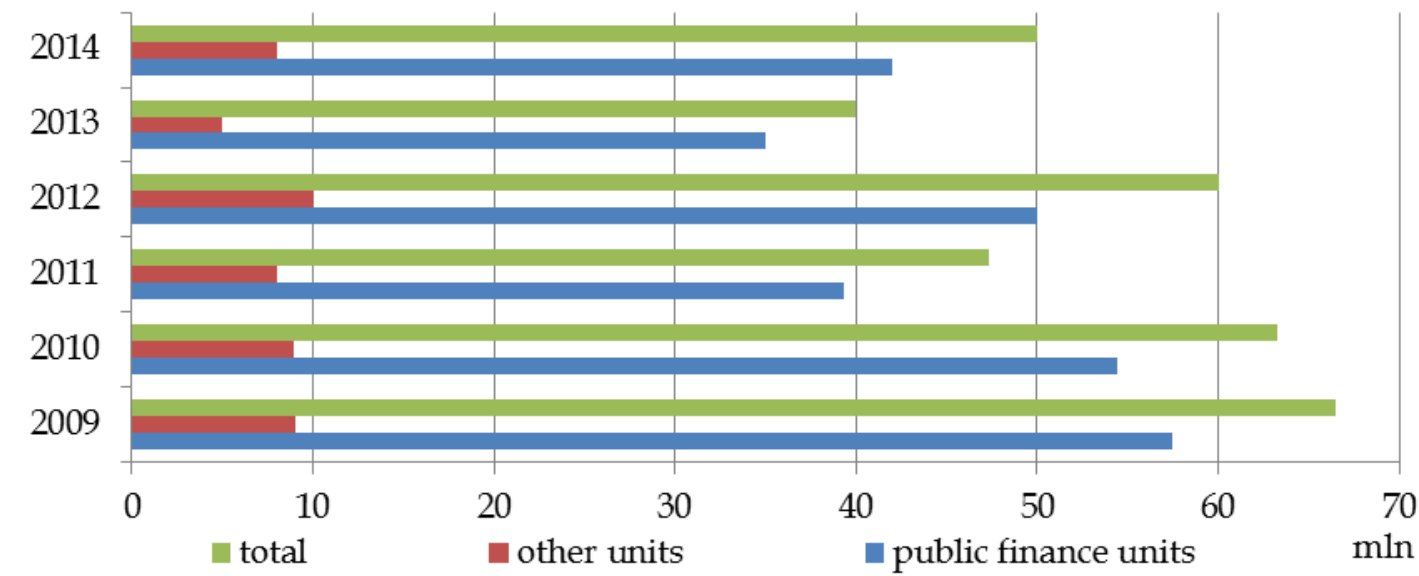

Fig. 1. Value and structure of aid granted by the APA according to the program of non-repayable financial aid. Source: own calculation based on APA data.

An analysis of the amount of non-repayable aid granted by the local branch of the APA in Olsztyn shows that aid granted to financial sector units dominated throughout the period under analysis. The proportion of other units which received such aid was relatively the greatest in the years 2004-2005. Of the total amount of PLN 164.4 million, about $81.6 \%$ was granted to units of the public finance sector, and $18.4 \%$ to other units. The highest amount of non-repayable financial aid was granted in the years 2004-2005, as well as in 2008 and 2010 (Fig. 2).

6. Assessment of the conditions under which property can be handed over free of charge by the APA local branch in Olsztyn

Pursuant to $\S 7.3 .1$ of the Regulation of the Minister of Agriculture and Rural Development of 16 March 2009 on detailed rules of financial management at the Agricultural Property Agency and

8 The index applied here corresponds to the solution proposed by professors: W. Karaszewski and S. Sudoł. (See W. Karaszewski, S. Sudoł: Empirical Research on the Process of Transformation of Polish Companies in the Period of 1990-1995, Wydawnictwo UMK, Toruń 1997, pp. 17-18). 
financial management at the Agricultural Property Assets of the National Treasury, communes and housing cooperatives can benefit from non-repayable financial aid 9 .

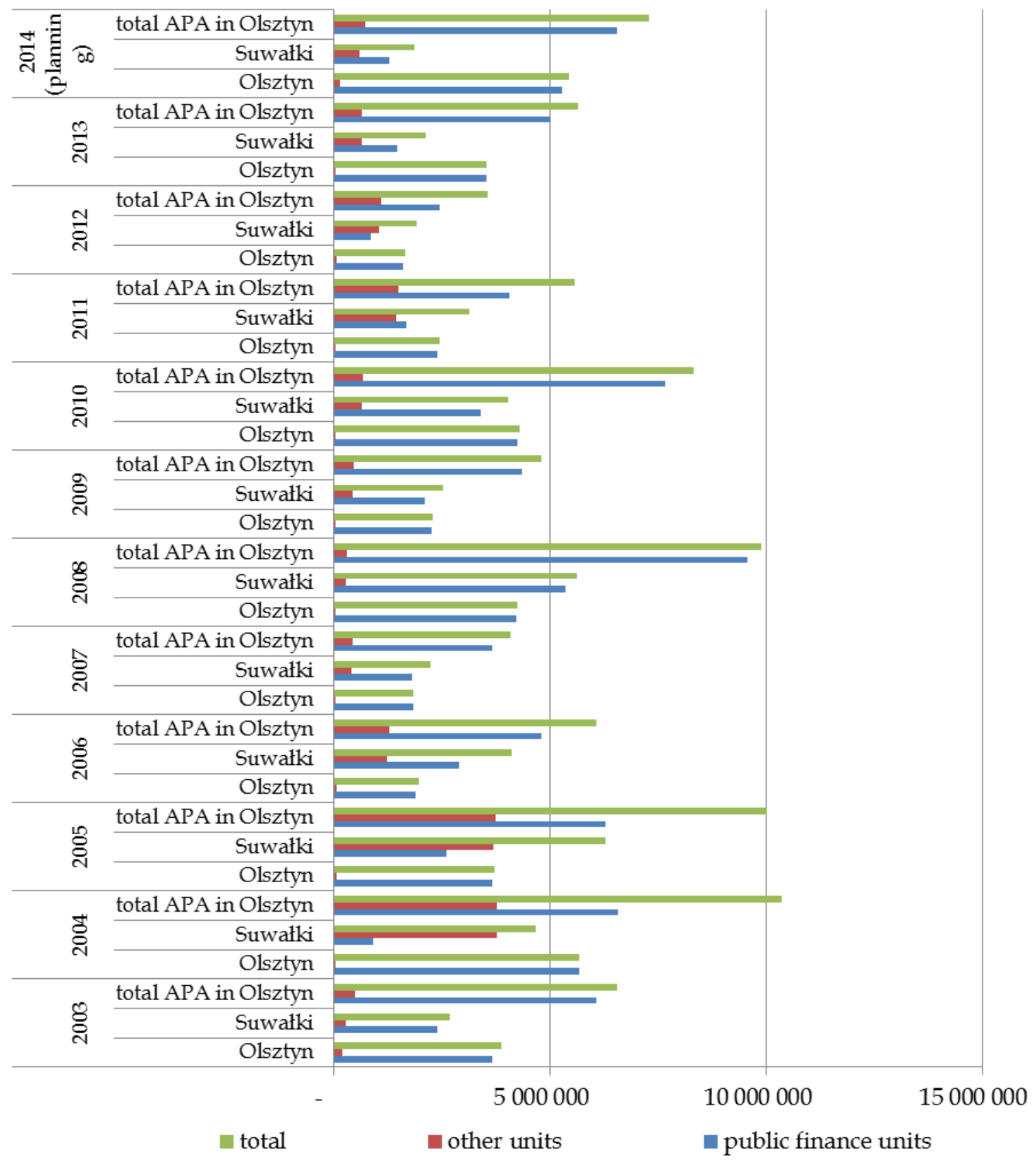

Fig. 2. Value of aid granted by the APA in Olsztyn in the years 2003-2014. Source: own calculation based on APA in Olsztyn data.

Therefore, the first part of the empirical research covered the following issues: assessment of the

${ }^{9}$ (1) communes and housing cooperatives which took over houses or flats and farm buildings, as well as the land that belongs to them from the Agency free of charge, under Art. 43.2 of the Act on Managing Agricultural Property of the National Treasury, (2) communes and housing cooperatives, created by purchasers of flats from the assets of the Agricultural Property of the National Treasury in order to administer residential buildings, which took over land with technical infrastructure facilities accompanying residential buildings together with the property necessary to use the infrastructure from the Agency under Art. 44 of the said Act, (3) communes to which the Agency handed over property with the necessary land, serving the purpose of conducting non-business activities, especially welfare facilities, cultural, sports, educational and healthcare facilities, under Art. 48 of the said Act. 
current technical condition of elements of the assets and their technical condition upon them being handed over by the APA, the significance of the resources that have been taken over in relation to the total communal assets, identification of the main problems associated with the resources that are being taken over, identification and assessment of the significance of actions that encourage communes to take over elements of assets still being part of APA assets and the difficulties related to taking over these assets.

land accompanying the above-mentioned real estates healthcare facilities educational facilities sports facilities cultural facilities social facilities

technical infrastructure farm buildings housing facilities houses

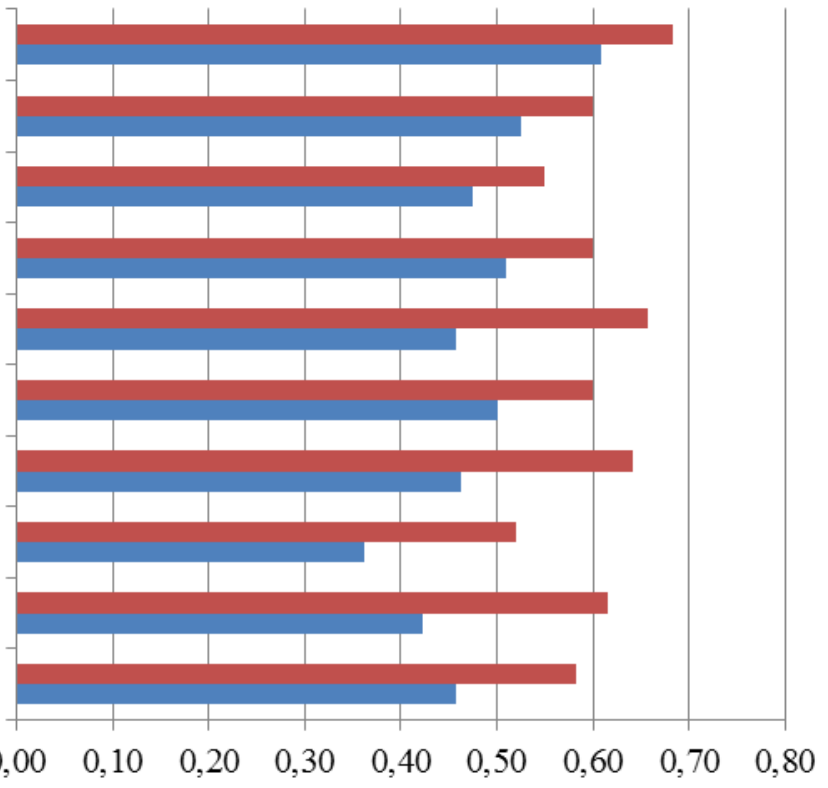

- current condition condition upon being taken over

Fig. 3. Assessment of the current technical condition of assets and upon being taken over from APA. Source: calculation based on own research.

land accompanying the above-mentioned real. healthcare facilities
educational facilities educational facilities sports facilities cultural facilities social facilities technical infrastructure farm buildings housing facilities houses

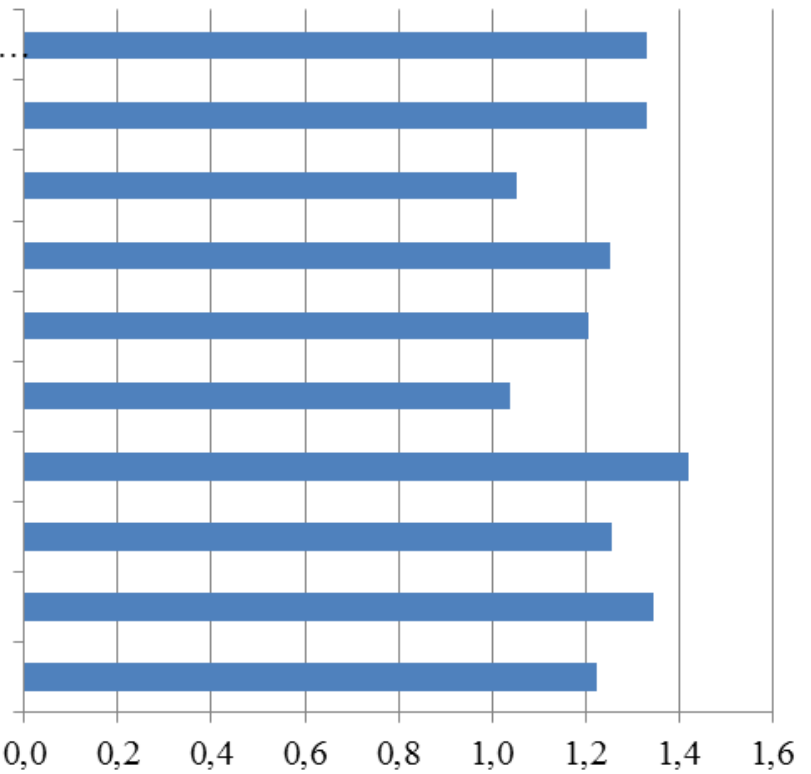

where: 1 - share to $20 \%, 5$ - over $80 \%$

Fig. 4. Assessment of the importance of the acquired asset in relation to the general assets of the commune. Source: calculation based on own research. 
staying in the locality of individual facilities

management in buildings partially sold housing facilities being leased by people who do not pay the rent

low technical condition of other facilities (educational, sports)

low technical condition of infrastructure

low technical condition of farm buildings

low technical condition of houses

location of housing facilities in buliding of low technical condition

high upkeep

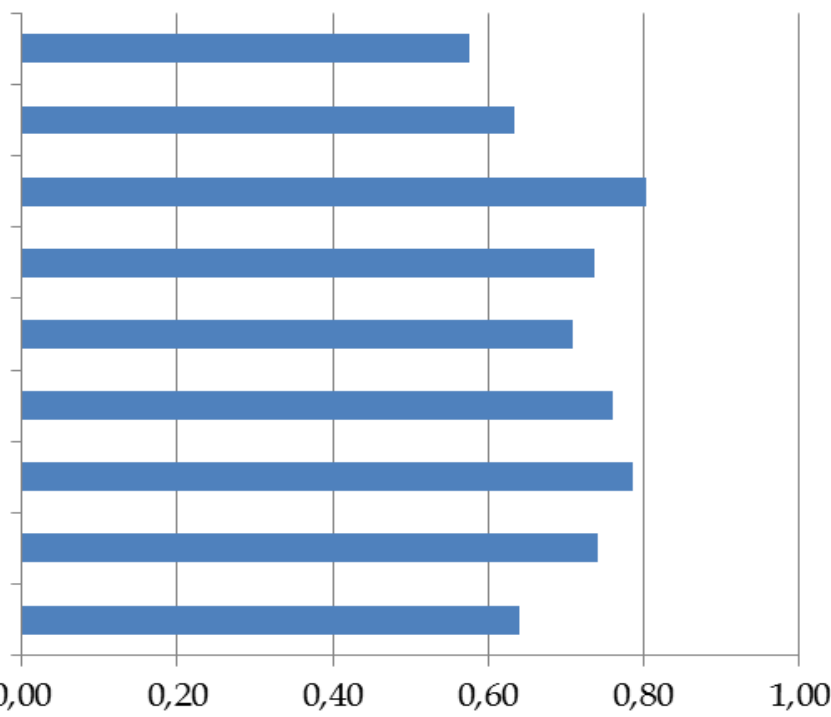

Fig. 5. Main problems associated with the acquired assets from the APA. Source: calculation based on own research.

The study has shown that, in the opinion of representatives of communal local governments which have taken over some assets, the technical condition of the assets upon them being taken over was assessed at $0.36-0.61$ score points (on the 0-1 scale). The lowest score was given for the technical condition of farm buildings. According to the respondents, the technical condition of the assets is now better, with that of housing and cultural facilities having improved to the greatest extent (Fig. 3).

The importance of individual elements of the assets to the communes which participated in the survey varied. In general, they accounted for $20-40 \%$ of all assets. Only elements of technical infrastructure accounted for not much more than $40 \%$ of communal assets (Fig. 4).

According to the report of the Supreme Audit Office (Informacja ...2014), there are still components of APA assets which could be handed over to other entities, but, for various reasons, are still being held by the APA. Therefore, the aim of the study was to identify and assess the importance of the main issues associated with the assets being taken over. According to the data in Fig. 5, representatives of local authorities not only regarded the issues as relatively numerous, but also their importance as great. All problems were defined as a great or large obstacle - an assessment score above 0.5 (in the $0-1$ scale). Housing facilities being leased by people who do not pay the rent was regarded as the most serious problem (index score of 0.80 ).

Despite previously diagnosed problems with taking over the individual components of assets, local authorities specified measures which could encourage different entities to take over those assets that are still being held by the Agency. The most important measures include increasing nonrepayable financial aid (54\% responses) and handing over housing facilities without tenants who do not pay the rent regularly (48\%) (Fig. 6).

Assets taken over by local governments also included land. Representatives of 70 out of the 73 local governments that took part in the survey confirmed that the local governments had received land from the APA. The land was mainly allocated for roads $(75 \%)$, under infrastructure $(68 \%)$ and under sports facilities $(53 \%)$.

The issues associated with the distribution of land which is being held by the APA have been discussed in many aspects, e.g. organization of the task, following the right procedures, or the method of management. Opinions about the pace of the process also vary. In the opinion of $80 \%$ of the representatives of local authorities, some difficulties occur in the process of taking over land from APA assets. The following were mentioned as the most important ones: prolonged procedures $(52 \%$ respondents) and a fear that if the objective was not achieved for reasons beyond the commune's control, the funds that would have to be returned for a piece of land property after a period of up to 10 years would be too large a burden for the commune budget (47\% of respondents). It was also emphasized that some procedures could last (and some had already lasted) as long as three years. The average procedure in the surveyed group took over 2 years (25 months) to complete. Other issues included unregulated legal status, a different purpose of the land in the local land use plan, or lack 
thereof, and overly-complicated procedures, including the number of required documents.

replacement of housing facilities to provide a more compact assets and easy for management

handing over housing facilities without tenants who do not pay the rent regularly

increasing non-repayable financial aid

our community hasn't such assets

\section{0}

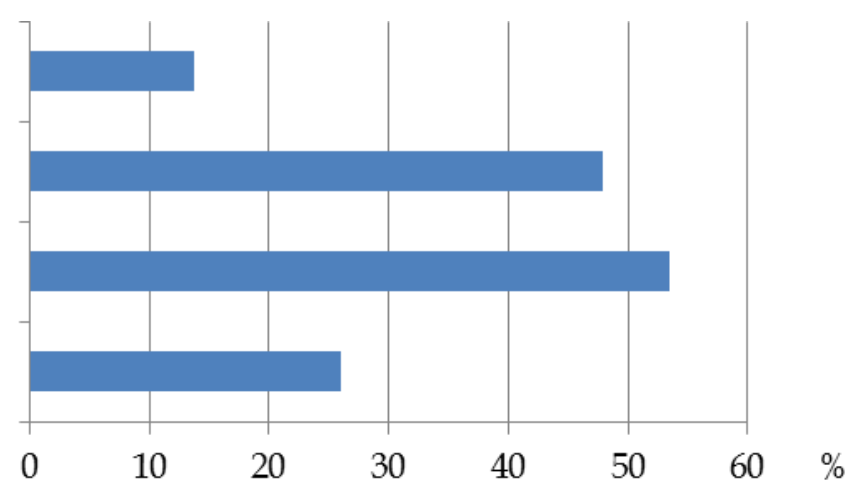

Fig. 6. Identification and assessment of the importance of activities encouraging local authorities to take over those assets that are still being held by the APA. Source: calculation based on own research.

\section{Assessment of the program of non-repayable financial aid granted to local governments made by} their heads

Non-repayable financial aid granted under a decision ${ }^{10}$ by the Agency can be only utilized for investment (repair) projects, which involve:

- repair or reconstruction of buildings, housing facilities, technical infrastructure, including roads within housing estates which were taken over, whose documented condition upon taking over confirms the need for reconstruction or repair, as well as connecting the buildings, housing facilities and technical infrastructure which were taken over, to existing communal technical infrastructure which is under construction, and

- construction of buildings, housing facilities and technical infrastructure only when they are to replace facilities which were handed over free of charge, whose repair is not economically justified; if the facility to be constructed was to expand the number of service consumers - only in the amount needed for the property which was or still is part of the assets and the other existing service consumers.

A large majority of local government representatives claim that the non-repayable financial aid is rather insufficient (48\%) and definitely insufficient (19\%). One of the factors which determine the use of non-repayable financial aid is the procedure of granting and utilizing it. The procedure is detailed in the agreement which the Agency concludes with a beneficiary before the start of a project subsidized with funds granted as part of the program of non-repayable financial aid ${ }^{11}$.

The opinions of representatives of local governments varied; on the one hand, $38 \%$ of those who expressed their opinions on the matter claimed that the procedures of applying and utilizing non-repayable financial aid are definitely, or rather, complicated, but at the same time, $38 \%$ representatives of local government representatives had different opinions on the matter.

Conditions under which non-repayable financial aid is granted include, on the one hand, the need for meeting certain requirements by potential beneficiaries, but also the size of the property being handed over by the APA. As has been shown, for example, by an audit conducted by the Supreme Audit Office in regard to managing the housing facilities previously owned by state-run agricultural farms or other entities which owned housing facilities (Informacja...2011), transferring flats was met with a lot of obstacles. Local branches faced a lack of interest on the part of communes, which were

10 The decision should be preceded by a written evaluation of its justifiability, made on the basis of the information obtained both from the beneficiary and from other available sources.

11 Detailed conditions are laid down in an agreement between the Agency and the beneficiary, which contains a detailed description of the undertaking, the cost of carrying it out, participation of the Agency and other entities in financing the enterprise, schedule of execution, and conditions of transferring the funds. Funds are transferred upon: confirmation of the completion of the schedule, meeting other conditions upon which the Agency makes its participation in financing the enterprise conditional, the form and time limits of confirmation by the beneficiary that the undertaking has been completed, the final deadline for the financial settlement, the Agency's right to carry out direct audits, obligating the beneficiary to observe the regulations of the public procurement act, the circumstances in which the Agency is entitled to withdraw from the agreement, any claims to which the Agency is entitled should the beneficiary fail to fulfil its part of the agreement, forms of securing the Agency's claims. 
unwilling to take over facilities if this was associated with additional costs. Also, the order given by the President of the APA in 2009 to set up actions aimed at handing over all flats whose tenants did not make a declaration of their intention to purchase them within a set time limit, to communes or housing cooperatives. An analysis of the dynamics of sale indicated that if the current sale rate is maintained, all the flats will have been sold within a dozen years. However, the long process of selling the flats which are included in the assets is not economically justified.

\section{Summary}

The Agricultural Property Agency is an institution which has been assigned various tasks. It is a public authority agency which is a part of the public finance system. Its tasks were laid down in the act on managing the agricultural property of the National Treasury, and its scope of responsibilities was expanded by the act on creating the system of agriculture. The main tasks concern ownership transformations in agriculture and developing the required structure of farms in terms of their area. Other important, less common, tasks include granting non-repayable financial aid to communes and housing cooperatives, as well as government and communal entities which take over devices, facilities and networks.

The assets managed by the APA still include different components which should be permanently disposed of. However, there are a number of obstacles which hinder such actions. On the one hand, the Agency must accomplish tasks in an economically sound manner and, as the Supreme Audit Office has emphasiszed in its reports, the Agency should dispose more intensely of those assets which it is not economically justified to maintain and, at the same time, the possibility of handing over such assets free of charge is not a decisive factor in the handing over process. This is because the cost of maintenance of certain assets may exceed the benefits gained.

As has been shown in the survey conducted among representatives of local governments, the interest of communes in taking over assets still held by the local branch of the APA in Olsztyn could be increased by limiting the number of tenants who do not pay rent regularly and by increasing the amount of non-repayable financial aid. The latter action could be carried out, but the former could prove to be extremely difficult.

\section{References}

Blauberger M. 2009. Of 'Good' and 'Bad' Subsidies: European State Aid Control through Soft and Hard Law. West European Politics, Volume 32, Issue 4, pp. 719-737.

BRZUSKA E., 2014, Pomoc publiczna w Polsce w kontekście polityki gospodarczej państwa (State aid in Poland the contex of economic policy of the state) in: Polityka gospodarcza w okresie transformacji i kryzysu, Red. A. Barteczek, A. Rączaszek, Sigillum Universitatis Oeconomicae, Katowice, pp. 58-65.

Informacja o wynikach kontroli wykonania w 2013 r. planów finansowych Agencji Nieruchomości Rolnych (Information about the results of monitoring the implementation in 2013 financial plans of Agricultural Property Agency), 2014, Najwyższa Izba Kontroli, Departament Rolnictwa i Rozwoju Wsi, Warszawa.

KARASZEWSKI W., SUDOŁ S., 1997, Empirical Research on the Process of Transformation of Polish Companies in the Period of 1990-1995, Wyd. UMK, Torun, pp. 17-18.

KISIEL R., KAMIŃSKA M., LIZIŃSKA W., 2014, Value and Structure of Public Aid in Poland Against the European Union Background During the Years 2007-2012, Olsztyn Economic Journal, 9 (1/2014): 1730.

KUBERA P., 2013, Ocena skuteczności i efektywności instrumentów pomocy publicznej, in: Efektywność zarządzania organizacjami publicznymi i jej pomiar, Red. A. Frąckiewicz-Wronka, UE, Katowice, pp. 96-109.

LINNER H., MESSINGA I. 2012. Agricultural land needs protection. Acta Agriculturae Scandinavica, Section B - Soil \& Plant Science, Volume 62, Issue 8, pp. 706-710.

MARKS-BIELSKA R., 2012, Interwencyjna rola Agencji Nieruchomości Rolnych na rynku ziemi rolniczej (The interventionist role of the Agricultural Property Agency in the market of agricultural land), in: Przemiany w rolnictwie i na obszarach wiejskich z udziałem Agencji Nieruchomości Rolnych na przykładzie województwa warmińsko-mazurskiego, Red. R. Kisiel, R. Marks-Bielska, UWM, Olsztyn, pp. 4978. 
MARKS-BIELSKA R. 2013. Factors shaping the agricultural land market in Poland. Land Use Policy, 30, ELSEVIER; pp. 791-799.

MARKS-BIELSKA R., BABUCHOWSKA K., LIZIŃSKA W., 2013, Stare i nowe zadania Agencji Nieruchomości Rolnych w unowocześnianiu rolnictwa i obszarów wiejskich (Old and new tasks Agricultural Property Agency in the modernization of agriculture and rural areas), in: Rola Agencji nieruchomości rolnych w unowocześnianiu rolnictwa i obszarów wiejskich, Red. R. Marks-Bielska, R. Kisiel, UWM, Olsztyn, pp. 97-117.

MARQUARDT P., 2007, Pomoc dla matych i średnich przedsiębiorców (Support for small and medium-sized enterprises), Wyd. LexisNexis, Warszawa.

Müller-Ibold T. 2014. Developments in EU State Aid Law. Competition Policy International, Vol. 5 No. 2.

NARLOCH Ł., 2013, Pomoc publiczna dla przedsiębiorstw - czy warto jej udzielać?(State aid for enterprises - is it worth to grant?) Zarządzanie i Finanse. Journal of Management and Finance, Wydział Zarządzania, Uniwersytet Gdański, Vol. 1, No. 1, part 1, pp. 473-488.

PieTRZAK B., POlAŃSKi Z., WoŹNIAK B., 2006, System finansowy w Polsce (The financial system in Poland), PWN, Warszawa.

PodsiAdŁo P., 2013, Pomoc publiczna na wspieranie rozwoju sieci szerokopasmowych w Unii Europejskiej (Public aid to support the development of broadband networks in the European Union), in: Mechanizm funkcjonowania strefy euro, Wybrane problemy, IV. Ed. S. Owsiak. Krakowska Szkoła Biznesu Uniwersytetu Ekonomicznego, Kraków.

Program pomocy środowiskom popegeerowskim (The aid programs for State Farm community), 2009, Biuletyn Informacyjny, MRiRW, ARiMR, Warszawa, 7-8(130): 16-17.

RUTKIEWICZ K., 2014, Pomoc publiczna na restrukturyzację górnictwa wegla kamiennego w świetle polityki konkurencji Unii Europejskiej w latach 2002-2010 (State aid for restructuring of the hard coal mining industry in the European Union's competition policy in the period 2002-2010), in: Polityka gospodarcza w okresie transformacji i kryzysu, Red. A. Barteczek, A. Rączaszek, Sigillum Universitatis Oeconomicae, Katowice, pp. 261-271.

SOSNOWSKI M., 2011, Podatkowy wymiar pomocy publicznej (Tax dimension of state aid), in: Finanse publiczne. Prace Naukowe Uniwersytetu Ekonomicznego we Wrocławiu, nr 167, Red. J. Sokołowski, A. Żabiński, UE, Wrocław, pp. 423-437.

STANKIEWICZ W., 2007, Historia myśli ekonomicznej (History of Economic Thought), PWE, Warszawa. STIGLITZ J.E., 2004, Ekonomia sektora publicznego (Economics of the public sektor), PWN, Warszawa.

SzReder J., WalentYNOWiCZ P., 2014, A New Way of Investing on the Agricultural Real Estate Market in Poland. Real Estate Management and Valuation. Vol. 22, Issue 1: 5-12. 